\title{
POLA KERUKUNAN UMAT BERAGAMA DI BANYUMAS
}

\author{
Rahmini Hadi \\ Institut Agama Islam Negeri Purwokerto \\ Jl. A. Yani 40-A (+62-281) -635624 Purwokerto 53126 \\ E-mail: rahmini_hadi@gmail.com
}

\begin{abstract}
This research aims to describe and explain the importance of harmony among religious community in Banyumas area. The preventive actions are needed since there are only researches on the solving problems only. This research is focused on the actions which results in the peaceful of religious in social relation ethnographically. The analysis concept of this research is to study the fact about cultural value which construct the interreligious harmony. Ethnographies description tries to reveal the way of life in various subjects and construct a concept and action in life. The research found, first the intereligous harmony causes by the tolerance of the society for their differences, second; the harmony is built on a sole circle of socio-cultural act. Third, the harmony of the pople is created by the understanding of high value of life.
\end{abstract}

Abstrak: Tulisan ini berusaha untuk mengungkap mengenai pentingnya kerukunan umat beragama di Banyumas. Tulisan ini menelisik mengenai upaya-upaya pencegahan yang perlu dilakukan agar kerukunan umat beragama tetap terjalin. Banyak penelitian terkait meneliti kerukukan umat beragama pada sisi penyelesaian, bukan pada tindakan pencegahan. Penelitian ini lebih tertuju pada tindakan yang menyebabkan damai dalam relasi sosial umat beragama secara etnografis. Konsep analisis ini dengan mengacu pada etnografi terkait pada situasi budaya yang ada di Banyumas berdasarkan institusi sosial yang ada. Selama ini, memang di Banyumas tampak tenang-tenang saja, adapun yang perlu dikaji apakah nilai budaya yang membentuk keharmonisan antarumat beragama itu terbentuk. Deskripsi etnografis berusaha mengkaji pandangan hidup, dengan berbagai disiplin yang membentuk konsep dan tidakan dalam kehidupan. Temuan dalam penelitian ini dapat tersurat dalam beberapa hal; Pertama, harmonisasi kerukunan umat beragama di Banyumas terjadi karena ada rasa toleransi masyarakat terkait dengan perbedaan; Kedua, harmonisasi kerukunan umat beragama di Banyumas umat beragama terbentuk oleh 
tindakan sosial budaya yang masih dalam satu lingkaran; Ketiga, k harmonisasi kerukunan umat beragama di Banyumas dapat tercipta melalui pemahaman nilai luhur, walaupun ada sisi yang berubah mengjadi global.

Kata Kunci: harmonisasi, budaya, Banyumas, radikalisasi, dan agama

\section{A. Pendahuluan}

Kasus mengenai kekerasan dan konflik berbasis agama tetap saja membuat kekhawatiran dan menjadi isu yang tidak boleh dianggap remeh. Sempat beberapa tahun lalu konflik di Poso antara umat Islam dan Kristen yang menelan korban hingga ribuan orang yang kini telah berhasil dipadamkan. Kekerasan umat beragama juga sempat terjadi di Madura 2011 yakni antara warga Syiah dan Sunni dengan turut pula membakar rumah dan pesantren (dalam fokus. news.viva.co.id, 2013). Konflik ini bermula dari konflik keluarga yang merembet ke dalam permasalahan agama karena adanya aksi saling serang. Kekerasan dengan mengatasnamakan agama tidak hanya menjadi masalah di Indonesia saja, melainkan juga menjadi masalah internasional seperti kasus terorisme di Amerika yang meruntuhkan dua menara kembar dengan dalih agama Islam di baliknya. Terorisme muncul tidak hanya sekadar teror, namun mereka membawa latar belakang Islam di baliknya sehingga tindakan yang dilakukan dapat dikategorikan sebagai kejahatan berbasis agama. Dalam kasus semacam ini, mereka mungkin saja gagal atas ulah dari mereka dan kegagalan seperti itu justru akan memunculkan stigma negatif at as agama tertentu (Machan, 2006: 4).

Kekerasan dengan mengatasnamakan Islam kini juga muncul dengan adanya Islam of State Irak and Syiria (ISIS) yang berulangkali menampilkan video kekejaman mereka di internet (dalam international.sindo.news.com, 2015). Dengan mengatasnamakan kebenaran untuk membunuh orang lain, mereka memandang hal itu sebagai realitas yang dilakukan dengan dipenuhi keyakinan. Oleh karena itu, perlu untuk setiap elemen masyarakat memberikan penjelasan terkait hakikat agama yang sebenarnya. Hal ini karena perekrutan anggora ISIS tidak hanya dari negera tertentu saja, melainkan di mana pun dan tidak bisa terduga. Dalam pandangan Skowlimowski (2004: 12), setiap orang perlu untuk diberi kesadaran mengenai lingkungannya agar tidak terjermus dalam hal-hal yang tidak diharapkan. Bagaimanapun juga penanaman "sistem nilai" sejak dini sebagai dasar pemahaman seseorang menjadi sangat penting unt uk membekali pandangan dalam pergaulan, cara menentukan baik dan benar, juga seleksi informasi sebagai ideologi.

Dalam konteks semacam ini, suatu tatanan yang mula menghilang adalah 
upaya untuk memberikan pendidikan agama pada ranah harmonisasi budaya. Setiap agama selalu memberikan pandangan mengenai kebenaran dan menjadikan dirinya yang paling benar, hanya saja perlu diajarkan pula untu memberikan pandangan agar menghormati agama lain. Dengan membuka pandangan setiap orang sebagai yang berbeda, namun masih dalam satu naungan, maka akan membentuk kesadaran menjadi satu kesatuan walau dalam konteks perbedaan. Kondisi inilah yang diidealkan oleh Indonesia dengan konsep keberbedaannya. Perkenalan, pemahaman mengenai hakikat hidup, juga penanaman nilai-nilai kebersamaan dalam perbedaan sudut pandang agama menjadi sangat penting untuk dilakukan.

Dalam penelitian ini akan diarahkan perhatian pada ranah pendidikan harmonisasi budaya di Banyumas dengan mengacu pada keberagaman agama yang ada, di samping memang masih memiliki nilai-nilai luhur yang dipahami dan dilestarikan. Dengan memandang Banyumas sebagai daerah yang religius, dapat diidentifikasi pula bentuk-bentuk pendidikan yang sejalan dengan nilai budaya. Dalam konteks sejarah, di mana Banyumas merupakan percampuran antara Sunda dan Yogya membentuk hierarki sebagai sama-sama orang rendahan. Oleh karena itu, selain telah dibentuk dalam tradisi untuk saling menerima, juga menyadari bahwa sebagai orang rendah yang tidak perlu untuk saling menyatakan kebenaran dalam fanatisme. Melihat keadaan yang penting tersebut, Banyumas dapat dipotret sebagai ranah pembentukan dan pelestarian rasa aman. Hal ini bukan berarti bahwa perumusan dan konseptualisasi nilai-nilai tidak perlu untuk dilakukan. Justru pemupukan nilai-nilai melalui pranata, institusi, dan pengarahan wacana sejak dini harus menstruktur dalam kehidupan masyarakat Banyumas secara ideal.

\section{B. Budaya dan Strategi Interpretatif}

Menurut Barker (2008: 12), pendekatan yang masuk dalam ranah budaya masyarakat tidak hanya menggunakan metode interpretatif dan hermeneutis untuk mengungkap makna 'tersembunyi' bahasa, melainkan juga memberikan perhatian kepada deskripsi dan analisis diskursus secara mendalam. Budaya selalu memunculkan kemungkinan makna dari jejak yang ada berdasarkan konstruksi sosial. Untuk sampai pada praktik sosial, tulisan juga memerlukan seperangkat konsep untuk membongkar kebenaran dalam tatanan masyarakat Banyumas. Antara kehidupan, jejak, dan relasi sosial harus jelas untuk diungkap dengan strategi tertentu yang telah dipersiapkan oleh seorang peneliti. Selain it u, digunakan pulan pendekatan dari tafsir kebudayaan berusaha mencari pemahaman makna dari ekspresi kebudayaan, daripada sekadar mencari 
hubungan sebab-akibat dalam kehidupan keberbudayaan.

Suatu budaya senantiasa memiliki nilai luhur dengan pranata yang melingkupinya. Budaya orang Jawa dalam membentuk tata perilaku hidup dilaksanakan dengan sudut pandang untuk menghormati dan membentuk kerukunan. Budaya tidak hanya dipandang dari segi adat dan kebiasaan saja, melainkan juga pada kebiasaan dan tata perilaku untuk membentuk hidup yang tenteram (Hazlitt, 2003: 45). Moral dipandang sebagai suatu pemahaman atas kehidupan untuk membedakan baik dan buruk, sekaligus sebagai pengendali atas tindakan individu. Moral dalam sebuah agama tidak terlalu berbeda dengan agama lainnya, contoh menutup aurat juga diajarkan oleh banyak agama sebagai kesucian diri. Moral agama menjadi pemahaman penting bagi masyarakat untuk menuju pada penghormatan kepada makhluk lain agar senantiasa menciptakan kedamaian bagi alam semesta ini. Nilai moral yang dibentuk agama, maka lamakelamaan akan menjadi budaya apabila dilestarikan dari waktu ke waktu. Hal inilah yang disebut sebagai nilai luhur.

Adapun mengenai harmonisasi budaya akan terbentuk dengan kesadarankesadaran suatu masyarakat dalam menghormati orang lain berdasarkan budayanya. Adanya kerukunan dan ketertiban telah dipandang oleh suatu masyarakat sebagai hal yang bernilai luhur (Skolimowski, 2004: 106). Salah satu usaha untuk membentuk kerukunan adalah dengan menjaga nilai luhur atas lingkungan. Nilai luhur tersebut harus disikapi dengan lembut agar tidak terjadi dominasi secara membabi-buta sehingga tidak ada toleransi. Pemahaman mengenai toleransi dalam lingkungan inilah yang penting untuk membentuk kerukunan. Mereka menyikapinya dengan halus dan lembut, serta sebagai hal yang ingin diajarkan pada anak. Harmonisasi budaya adalah satu kesatuan dari nilai nilai luhur yang diimplementasikan dalam prilaku kehidupan sehari hari. Oleh karena itu, pandangan ini mengacu pada pemahaman secara kebersamaan dan satu kesatuan.

Moh. Roqib (2009: 16) pernah menulis tesis berjudul "Harmoni dalam Budaya Jawa: Dimensi Edukasi dan Keadilan Gender". Dalam tulisan itu, ia memandang bahwa budaya Jawa penuh dengan harmonisasi yang representasinya muncul dalam kehidupan tokoh Srintil dalam novel Ronggeng Dukuh Paruk, yang merupakan ikon dari orang Banyumas. Orang Jawa sendiri akan dikatakan "belum Jawa" kalau dalam hidupnya masih saja "belum berbudaya". Dengan demikian, budaya Banyumas itu sendiri seharunya telah menyatu dengan erat karena dituturkan, diajarkan, dan diwariskan. Segala ajaran-ajaran di dalam budaya Banyumas it u sendiri memiliki maksud yang baik bagi kehidupan. 
Heru Kurniawan (2010) memiliki pendapat yang menarik dalam artikel berjudul "Dialogisasi Kesadaran Kolektif dalam Relasi Antarumat Beragama pada Masyarakat Banyumas". Dalam tulisan itu, ia memfokuskan kajian kerukunan yang terbentuk di Banyumas melalui ranah dialog interaktif dari masyarakat yang berbeda agama. Keberbedaan bukanlah sebuah masalah selama mereka saling menjaga dan hidup bersama. Ia mengabil sampel di daerah perkotaan dan perdesaan yang memiliki keberbedaan agama. Dari hal tersebut, adanya toleransi, struktur nilai, serta dialogisasi yang berlangsung secara humanistis dan religius. Hanya saja, dalam penelitian tersebut, tidak mengarah pada upaya-upaya dalam membaca dan membentuk ranah pendidikan yang kelak dapat membentuk harmonisasi budaya pada ranah sistem nilai. Konsep dan pandangan inilah yang dalam penelitian ini akan dikaji secara mendalam untuk menganalisis bentuk dan penerapan dalam kehidupan sehingga dapat dilestarikan dan dikembangkan.

Kekerasan dengan mengatasnamakan agama dapat diartikan sebagai tindakan radikal berdasar agama. Radikalisasi adalah usaha untuk menjadikan tindakan dan perilaku yang keras (Ar-Razi, 2000: 46). Prosesnya dapat dilakukan dengan berbagai macam cara, bahkan sampai pada pembunuhan. Radikalisasi agama diartikan sebagai suatu proses untuk menjadikan agama yang memiliki tindakan keras dalam menentang hal yang boleh dilakukan dan tidak boleh untuk dilakukan. Cara menyikapi dan bertindak dengan keras tanpa memandang hukum negara menjadi prinsip sebuah agama dianggap radikal karena menggunakan hukum mereka sendiri (Iqbal, 2002: 67). Padahal, mereka berada di bawah negara yang juga memiliki dasar hukum yang jelas.

Konflik antarumat beragama itu terjadi, namun ada hal lain yang melatarbelakanginya. Konflik antarumat beragama terjadi dengan adanya kesalahpahaman berdasar pada situasi dan kondisi karena ketidakadilan, kesenjangan dan persoalan kekuasaan. Satu hal yang perlu dicermati bahwa radikalisme agama menyebar melalui kader organisasi dan jaringan tertentu. Usaha untuk pengenalan toleransi dengan orang lain dapat dilakukan pranata sosial dan budaya. Suatu penelitian budaya bukan hanya interpretasi atas kejadian saja, melainkan lebih pada pemerincian tatanan institusional mengenai fenomena sebagai integrasi sosial dan sistem sosial. Dalam hal ini, interpretasi juga sampai pada menggali makna yang terdapat dalam sistem dan strukt ur yang ada di Banyumas. Hal tersebut dipandang sebagai teks agar lebih terfokuskan pada pembacaan yang menghasilkan arena baru. Seluruh tatanan kehidupan di Banyumas yang membentuk kerukunan ini dipahami sebagai fenomena yang 
akan memunculkan makna-makna tersendiri. Wilayah itulah yang kemudian dikenal sebagai entitas untuk dapat dimaknai secara khusus.

\section{Banyumas: Agama dan Budaya}

Banyumas sebagai subkultur dari Jawa tak pernah habis dan tak pernah selesai untuk ditelusuri, baik dari sisi budaya, sosial, maupun filosofi. Selalu ada yang tak terungkap dan tersembunyi dari Banyumas karena ia dapat diposisikan sebagai "ruang yang memiliki kompleksitas" dalam strukt ur dan sistem yang telah mencapai keberadabannya. Tatanan modern—seperti keberadaan pabrik, pusat perbelanjaan, juga teknologi — di Banyumas itu sendiri bukan untuk dihalangi. Masyarakat harus berani berkomitmen bahwa yang modern itu tidak akan mengganggu dan mengubah stabilitas masyarakat yang religius.

Sebagai sebuah catatan (perlu untuk diketahui kiranya) bahwa dalam sejarahnya, Banyumas adalah saripati dari dua kekuatan besar Jawa, yakni Padjajaran dan Majapahit. Bahasa yang digunakan oleh mayarakat Banyumas adalah bahasa Jawa pertengahan yang tergolong cukup tua, yakni bersumber dari bahasa Kawi-meskipun dalam praktiknya sudah mengalami campuran dengan berbagai macam variasi. Secara geografis, Banyumas adalah transisi antara Sunda dan Yogyakarta, maka tidak heran bila Banyumas-yang oleh beberapa pakar dikatakan sebagai subkultur Jawa - menyimpan nilai-nilai luhur, lengkap dengan berbagai macam filosofinya. Oleh karena itu, Banyumas menyimpan nilai luhur Jawa secara historis dengan berbagai varian yang tersebar dalam rutinitas, dan ia pun membentuk artikulasi atas budaya Jawa.

Moh. Roqib (2009: 39) melalui buku Harmoni dalam Budaya Jawa berusaha melakukan itu dengan sangat sadar bahwa budaya msyarakat Banyumas memiliki harmoni, yang terepresentasikan melalui tata kehidupan. Ini menjadi menarik karena dia memiliki latarbelakang budaya Jawa yang baik. Belum lagi, praktik kebatinan yang membentuk moralitas dan tatacara dalam menjalin hubungan dengan Sang Pencipta. Konsep-konsep itu melekat dan bertransformasi, yang dapat ditelusuri jejak-jejaknya sebagai bagian dari budaya Jawa.

Orang Banyumas sendiri akan dikatakan "belum Banyumas" kalau dalam hidupnya masih saja "belum toleran" (Mulder, 1984: 110). Dengan demikian, budaya Banyumas itu sendiri seharusnya telah menyatu dengan erat karena dituturkan, diajarkan, dan diwariskan. Segala ajaran-ajaran di dalam budaya Banyumas itu sendiri memiliki maksud yang baik bagi kehidupan. Budaya Banyumas yang sebenarnya memberikan ajaran-ajaran secara tersembunyi: realitas simbolik yang dapat ditelusuri melalui etimologi, epistemologi, dan ontologi. Ajaran budaya Banyumas memberikan kesejahteraan, keselarasan, 
keberimbangan, dan ketenangan untuk hidup, yang dibentuk dalam etika sebagai pranata sosial. Dalam kaitan ini, budaya Jawa tidak hanya dipandang sebagai unit kecil yang penuh kekeliruan dalam berbagai penyimpangan masyarakat, namun sebagai kebijaksanaan hidup yang harus ditelusuri secara mendalam agar tidak muncul kesalahan pemahaman di masa sekarang. Kesalahan-kesalahan dalam moral, norma, maupun mitos harus diluruskan dengan mengacu pada kekuatan kosmis dalam etika yang bermartabat. Secara ut uh dan menyeluruh, ada wujud ideal, wujud kelakuan, dan wujud fisik kebudayaan yang terartikulasikan. Pranata-pranata dalam budaya Jawa apabila ditelusuri lebih "mendalam" mengarahkan pada kita untuk bisa hidup harmoni. Pandangan dunia orang Banyumas telah diformulasikan untuk dapat ditransformasikan di dalam kehidupan, dari dulu sampai sekarang, untuk mencapai interaksi yang berimbang.

Oleh karena itulah, ketika arus globalisasi makin kencang berputar melalui kebaruan-kebaruan pada sistem teknologi, informasi, dan komunikasi dengan juga menggeliatnya beberapa penyimpangan sosial, justru kearifan lokal dari budaya yang luhur menjadi sangat penting: sebagai identitas yang memiliki kompleksitas dengan kelenturan yang dapat diterima oleh berbagai elemen. Adapun usaha untuk menggali nilai luhur budaya Banyumas menjadi pekerjaan yang bijak, mengingat banyak orang yang sudah mulai mengabaikan budaya secara utuh dan terjerumus pada pergaulan yang keliru. Budaya Banyumas itu sendiri, tidak akan pernah habis, walau zaman bergeser dalam konstruks citra yang penuh gemerlap. Sumbangan pengetahuan tersebut menjadi sangat berharga kepada kita semua sebagai praktik maupun wacana berdasar pada ranah filosofis yang luhur.

Kehidupan masyarakat Banyumas, terutama pada kalangan muda sebagai agen perubahan, tokoh masyarakat, dan penyelenggara pendidikan merupakan ruang yang perlu dibentengi moral kebinekaan (filosofi Pancasila). Belakangan ini, pandangan masyarakat tentang Pancasila telah memudar. Dengan terbukanya ruang informasi global telah menjadikan masyarakat masuk dalam zona euforia. Nilai-nilai hanya dipandang sebagai beban hidup yang membosankan. Orang lebih takut pada disiplin dan hukuman. Dalam ranah inilah, disiplin dan hukuman harus mengacu dan melihat masyarakat yang berbeda, yakni melihat suatu permasalahan dari bermacam sisi sebagai bentuk pengendalian sosial.

Secara struktural, masyarakat di Banyumas banyak yang beragama Islam (80\%), namun juga ada agama lain, yakni Kristen, Budha, Hindu, dan Konghucu. Islam di Banyumas boleh dikatakan sebagai mayoritasnya, namun toleransi dan kerukunan yang terbentuk mencipta harmonisasi dalam satu ling- 
karan, yakni budaya Banyumas. Adapun tokoh masyarakat (kiai, pendeta, pemangku adat), pejabat pemerintahan yang terkait dengan agama, dan masyarakat menjadi subjek penting dalam membentuk kerukunan umat beragama. Ada arena plural yang berjalan melingkar sebagai pengendalian. Banyumas adalah miniat ur atas peristiwa budaya yang dilengkapi dengan konteks sosial, sekaligus yang menyajikan pandangan hidup berdasarkan norma, serta memiliki kaitan antara tradisi dengan pemahaman (mind). Ada pula ruang filosofi dan cara berpikir yang melandasi tradisi di seputar budaya Banyumas berdasarkan tradisi.

Masyarakat di Banyumas memiliki pemahaman menarik mengenai konsep toleransi untuk tempat ibadah (masjid) yang dekat dengan tempat ibadah lain (gereja) (Fadilah, 2014: 17). Hubungan antara tempat ibadah dengan lingkungan terbentuk dalam pemahaman mengenai rasa untuk menggunakan hak masing-masing, asalkan tidak mengganggu. Pemahaman mengenai "tidak mengganggu" ini ditanamkan dalam wujud budi pekerti berdasarkan budaya orang Banyumas untuk menerima (nrimo) kehadiran orang lain sebagai saudara. Perbedaan keyakinan bukanlah suatu masalah. Hal yang terpenting adalah rasa keguyuban dalam kehidupan sehari-hari. Oleh karena itu, posisi tempat ibadah yang berdampingan justru membentuk dialektika budaya tersendiri di tengah modernisasi dan masyarakat yang konon individual. Dengan adanya keguyuban itulah, terbentuk harmonisasi ketika hari-hari besar muncul. Misalnya, orang Islam turut menjaga keamanan bagi berjalannya Natal, atau orang Kristen turut mengamankan perayaan Idul Fitri. Hanya saja, pada prinsipnya, orang Islam dalam beragama tetap mengacu pada QS. alKāfirūn: 1-6.

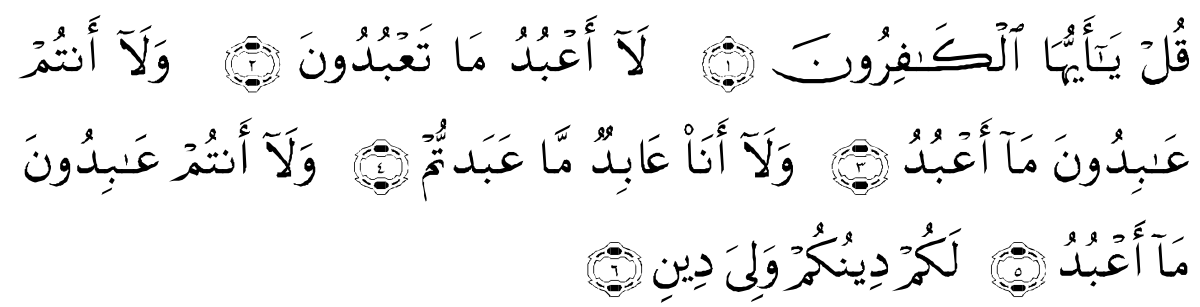

1. Katakanlah: "Hai orang-orang kafir (2). Aku tidak akan menyembah apa yang kamu sembah (3). Dan kamu bukan penyembah Tuhan yang aku sembah (4). Dan aku tidak pernah menjadi penyembah apa yang kamu sembah, (5). Dan kamu tidak pernah (pula) menjadi penyembah Tuhan yang aku sembah. (6). Untukmu agamamu, dan untukkulah, agamaku.”

Dari QS. al-Kāfirūn tersebut, konsep beragama bagi umat Islam memang sebuah pilihan. Dalam hal beragama, tidak ada paksaan. Sesuatu hal yang telah 
menjadi keyakinan memang tidak perlu untuk diubah. Ada kebebasan untuk menyembah. Semua memiliki hak masing-masing untuk memilih agama sesuai dengan keyakinan.

Dalam kehidupan, orang Banyumas menyadari tentang hak seseorang untuk memilih agama sesuai dengan keyakinannya. Adapun konsep keberhidupan secara sosial, orang Banyumas menekankan persaudaraan untuk membentuk harmonisasi antara yang satu dengan lainnya. Pemahaman sebagai sesama manusia adalah saudara dipahami berdasarkan QS. al-Ḥujurāt: 10-11.

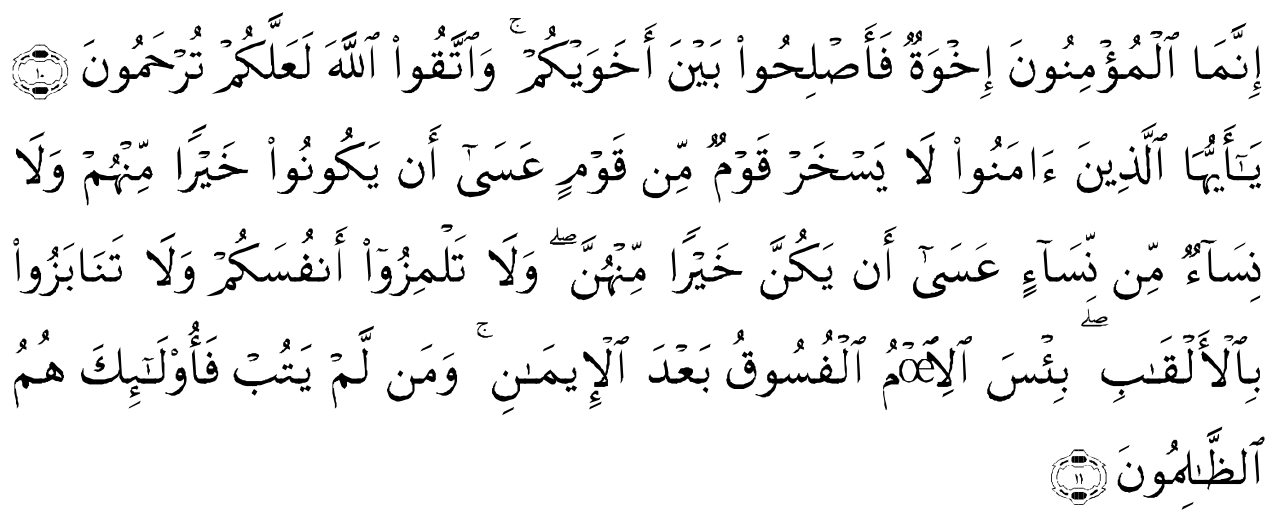

(10). Orang-orang beriman itu Sesungguhnya bersaudara. sebab itu damaikanlah (perbaikilah hubungan) antara kedua saudaramu itu dan takutlah terhadap Allah, supaya kamu mendapat rahmat (11). Hai orang-orang yang beriman, janganlah sekumpulan orang laki-laki merendahkan kumpulan yang lain, boleh Jadi yang ditertawakan itu lebih baik dari mereka. dan jangan pula sekumpulan perempuan merendahkan kumpulan lainnya, boleh Jadi yang direndahkan itu lebih baik. dan janganlah suka mencela dirimu sendiri ${ }^{l}$ dan jangan memanggil dengan gelaran yang mengandung ejekan. seburuk-buruk panggilan adalah (panggilan) yang buruk sesudah iman ${ }^{2}$ dan Barangsiapa yang tidak bertobat, maka mereka Itulah orang-orang yang zalim.

Dari QS. al-Ḥujurāt: 10-11 dipahami mengenai pentingnya persaudaraan sebagai bagian dari makhluk Allah. Sesama manusia tidak diperkenankan untuk saling merendahkan. Manusia memiliki nilai-nilai intrinsik yang penting untuk dipahami mengenai dinamika dan cakrawala pengetahuan mengenai perbedaan yang bisa dimaklumi dalam ranah persaudaraan. Kesadaran bahwa perbedaan dalam hidup bukan sebagai sebuah yang harus disamakan, melainkan untuk

${ }^{1}$ Jangan mencela dirimu sendiri. Maksudnya ialah mencela antara sesama karena orangorang mukmin seperti satu tubuh.

${ }^{2}$ Panggilan yang buruk ialah gelar yang tidak disukai oleh orang yang digelari, seperti panggilan kepada orang yang sudah beriman, dengan panggilan seperti: "Hai, fasik! Hai, kafir!" dan sebagainya. 
memiliki visi dan misi dalam satu lingkaran tertentu sehingga persaudaraan terbentuk.

Oleh karena itu, dalam interpretasi budaya di Banyumas, hal yang paling penting adalah tingkah laku dalam bentuk kepedulian, saling sapa, dan tindakan sosial sebagai satu lingkaran geografis yang masih memiliki satu kesatuan. Kebiasaan untuk ngendong misalnya, akan membentuk keakraban sebagai saudara asalkan memahami konsep bertamu yang baik. Hal ini bisa saja teraplikasi dalam tindakan yang saling sapa ketika bertemu (sebagai tindakan basa-basi), namun membentuk ikatan. Hal semacam ini akan semakin terikat manakala ada satu lingkaran kebersamaan, semisal acara ronda bersama, guyub dalam bersih desa, yang saling berbaur tanpa membedakan perbedaan agama.

Biasanya, sebuah konflik akan terjadi manakala terbentuk lingkaran-lingkaran yang sengaja dibatasi (baik oleh komunikasi maupun tatanan). Hal ini akan sangat rawan karena kedua kelompok telah merasa memiliki kemapanankemapanan untuk memperjuangkan ego. Kondisi semacam ini tidak terjadi di Banyumas dengan adanya keterbukaan dan dialog yang dijalin dalam Forum Kerukunan Umat Beragama (FKUB). Pada ranah ini, pemimpin saling bertemu untuk membuat program sosial budaya sebagai bentuk kerukunan.

\section{Kerukunan Masyarakat Banyumas di Tengah Globalisasi}

Sebuah kota tanpa hasil budaya akan dikelilingi dengan kehampaan: orang-orang hanya akan memburu mode, kehilangan identitas dan sejarah, kesibukan-kesibukan dalam waktu yang padat. Idealnya, sebuah kota yang maju memiliki budaya agar homogenisasi masyarakat terbentuk. Hal inilah yang dapat menjadi daya tarik dan konstruktif bagi pewaris tradisi intelektual yang lama dan besar untuk memahami setiap potensi yang ada di sekitar Banyumas.

Keberhasilan dan kesuksesan sebuah kota tidak hanya dipandang dari pembangunan-pembangunan di setiap penjuru, melainkan pada pola pikir masyarakat yang telah dibentuk dan disadarkan untuk mencintai lingkungannya sendiri. Usaha untuk mengenalkan budaya-budaya yang ada di Banyumas pada generasi penerus sesuai dengan nilai dan filosofi menjadi strategi empiris untuk membentuk cara pandang terhadap Banyumas di masa yang akan datang. Penafsiran itu bukan cara berpikir fut urolog, tepatnya lebih pada usaha untuk membentuk kesadaran mencintai Banyumas pada generasi penerus karena masyarakat harus sadar pada nilai intrinsik untuk pencerahan. Pemahaman pada budaya luhur harus tetap diperkenalkan agar ruang dialog terbuka tetap terbentuk agar tidak terjadi perselisihan akibat kesalahpemahaman. 
Banyumas jika hanya mengandalkan kemajuan pada mode dan glamor, sudah dengan sendirinya terbentuk mengikuti arus zaman. Banyumas sebagai kota dapat dipandang seperti jaring yang dapat terhubung dengan mana saja, maka itu kontruksi dan matrialisasi relasi sosial terbentuk sejalan dengan adanya interaksi itu sendiri. Regenerasi yang baik akan melekatkan pada budaya yang tidak luntur, di satu sisi juga tetap tidak ketinggalan dengan berbagai perkembangan informasi global untuk merespon keberagaman dalam perubahan tanpa henti. Pemerintah juga harus terlibat dalam kebijakankebijakan untuk mengontrol ekologi perkotaan dalam merespons ruang-ruang publik. Pusat perbelanjaan, industri, transportasi dan dunia pendidikan adalah arena hubungan sosial yang harus dikontrol dan memberi daya tawar realistis bagi generasi penerus. Pada arena itu, dapat dilekatkan ikon budaya Banyumas sebagai perkenalan awan, dan persentuhan interaksi keseharian sehingga lanskap perkotaan dihiasi oleh representasi budaya, sekaligus sebagai identitas. Yang paling dapat dilihat pada arsitektur, tak menutup kemungkinan pada sisi lain, dengan tetap menampilkan rasa modern dari budaya Banyumas.

Persinggungan dua budaya dalam kota memang tidak dapat dipungkiri. Sebuah kota yang lupa pada sejarah luhur akan mengalami kematian metafisik. Dalam artian kehilangan ruh. Ruang kolektif_-sebagai persinggungan dan interaksi sosial — bila tidak dicermati dengan baik akan mengganggu stabilitas dan kontrol sosial agar tidak dipenuhi dengan konsumsi semata. Dua budaya dalam kota tent unya harus hati-hati agar tidak terjadi percampuran dan penggabungan ruang yang dapat menciptakan ketegangan fungsional.

Apabila ingin menyikapi permasalahan tersebut, maka di Banyumas harus meyakini bahwa hidup harmoni dengan lingkungan adalah ibadah. Pandangan ibadah tidak hanya mengacu pada ritual untuk berdialog langsung dengan Tuhan, melainkan juga dapat dilakukan dengan turut berpartisipasi menjaga keindahan lingkungan karena "sesungguhnya Tuhan juga mencintai keindahan". Orang-orang yang memahami hakikat semacam ini lebih banyak ditemukan di pondok pesantren yang memiliki kedalaman nilai dan rasa untuk mengenali dirinya sendiri dan mentransformasikan dalam hidup. Dalam dialektika lingkungan yang harmonis memang sudah seharusnya manusia memahami bahwa keindahan indrawi pun dapat menuju pada hakikat keindahan tunggal sang Pencipta.

\section{E. Simpulan}

Dari hasil pembahasan yang diulas pada tulisan ini, maka ada beberapa hal yang dapat dijadikan renungan terkait dengan kerukunan umat beragama di 
Banyumas. Pertama, harmonisasi kerukunan umat beragama di Banyumas terjadi karena ada rasa toleransi masyarakat terkait dengan perbedaan. Toleransi masyarakat Banyumas terbentuk oleh kesadaran sebagai sesama manusia sebagai saudara. Kedua, harmonisasi kerukunan umat beragama di Banyumas terbentuk oleh tindakan sosial budaya yang masih dalam satu lingkaran geografis menjadikan ada kerja sama. Hal ini dapat diwujudkan dengan dialog dan pertemuan antar tokoh dan pendekatan sosial sebagai bagian dari masyaraat Banyumas. Ketiga, harmonisasi kerukunan umat beragama di Banyumas dapat tercipta melalui pemahaman nilai luhur, walaupun ada sisi yang berubah mengjadi global. Nilai-nilai budaya untuk berdialog dalam ranah saling menghormati dapat menjadi pembentuk kedamaian tercipta.

\section{Daftar Pustaka}

Ar-Razi, Imam. 2000. Ruh dan Jiwa; Tinjauan Filosofis dalam Perspektif Islam (Imam Razi's 'Ilm al-Akhlaq) diterj. oleh H. Mochtar Zoerni dan Joko S Kahhar. Surabaya: Risalah Gusti.

Fadilah, Umatin dkk. 2014. "Menggagas Dakwah Pluralis: Studi tentang Religius Inklusif pada Masjid al-Ikhlas dan Gereja Kristen Jawa, Kelurahan Kranji Purwokerto Timur” dalam Raushan Fikr Vol. 4 No. 2 Juli 2014.

http://fokus.news.viva.co.id/news/read/275905-mengutuk-aksi-brutalpembakaran-pesantren diakses pada 29 Mei 2015.

http://international.sindonews.com/read/960637/45/kebiadaban-isis-di-irakbocah-disalib-hingga-dikubur-hidup-hidup-1423134659 diakses pada 29 Mei 2015

Hazlitt, Henry. 2003. Dasar-Dasar Moralitas. Yogyakata: Pustaka Pelajar.

Iqbal, Muhammad. 2002. Rekonstruksi Pemikiran Agama dalam Islam (The Reconstruction of Religious Thought in Islam terj. Ali Audah, Taufik Ismail, dan Goenawan Mohamad. Yogyakarta: Jalasutra.

Kurniawan, Heru. 2010. "Dialogisasi Kesadaran Kolektif dalam Relasi Antarumat Beragama pada Masyarakat Banyumas" Jakarta: Kementrian Agama Republik Indonesia.

Ma'arif, Syamsul. 2010. "Nalar Anarkisme Agama-agama: Antara Doktrin dan Relasi Sejarah" dalam Jurnal Harmoni, Vol IX, No. 36 Oktober-Desember 2010.

Machan, Tibor R. 2006. Kebabasan dan Kebudayaan: Gagasan tentang Masyarakat Bebas. Jakarta: Yayasan Obor Indonesia. 
Munip, Abdul. "Menangkal Radikalisme Agama di Sekolah" dalam Jurnal Pendidikan Islam Vol. 1 No. 2 Desember 2012.

Roqib, Moh. 2009. Harmoni dalam Budaya Jawa: Dimensi Edukasi dan Keadilan Gender. Yogyakarta: Pustaka Pelajar.

Skolimowski, Henryk. 2004. Filsafat Lingkungan terj. dari Eco-Philosophy: Designing New Tactics for Living. Terj. Saut Pasaribu. Yogyakarta: Bentang. 